\title{
Off-season Production of Tomato (Lycopersicon esculentum L.) Under Different Shading and Mulching Materials
}

\section{Milagros O. Liberato}

Ilocos Sur Polytechnic State College, Don Mariano Marcos Memorial State University

\section{Abstract}

Tomatoes during rainy season have low production in open field; thus, supply is low, consequently, the price is high. Potential of protected production should be explored, the study conducted to find best eco-friendly net covers and mulch on growth and yield of two tomato varieties under off- season production. Specifically, determined the best cover, variety and mulching material to achieve optimum yield of tomato plants,

Corresponding Author: Milagros 0. Liberato milagrosliberato@yahoo.com

Received: 23 April 2018 Accepted: 8 May 2018 Published: 4 June 2018

Publishing services provided by Knowledge

(c) Milagros 0. Liberato. This article is distributed under the terms of the Creative Commons Attribution License, which permits unrestricted use and redistribution provided that the original author and source are credited.

Selection and Peer-review under the responsibility of the IRCHE 2017 Conference Committee. interaction and correlation effects of microclimates like temperature and relative humidity under the tunnel, on the growth and yield of tomato and highest net income among different treatments and treatments combinations.

Split-Split Plot in Factorial Randomized Complete Block Design using three blocks, three floating row covers (UV Film, EFNC Blue, EFNC Green), two tomato varieties (Marimar F1 and Diamante Max F1) three mulching materials (Plastic mulch, Sawdust, Carbonized Rice Hull), was employed.

Eco-friendly net covers (EFNC) did not significantly affect the growth and yield of tomato. Similarly, the two varieties did not differ significantly in growth and yield, but mulching materials significantly affected the growth and yield parameter, Carbonized Rice Hull increased number of flowers, fruiting percentage and fruits developed, plastic mulch produced highest yield with $3681.13 \mathrm{~kg} / \mathrm{ha}$.

No significant interaction effect among eco-friendly cover, variety and mulch on growth and yield parameter. Higher temperatures inside the tunnel improved the growth of tomato plants but made the fruits lighter and lowered yield and income per hectare. High relative humidity (\%) inside the tunnel increased weight of marketable fruits per plot and yield per hectare.

Keywords: eco-friendly net covers, mulching materials, relative humidity, temperature, UV films

\section{G OPEN ACCESS}




\section{Introduction}

Tomato, Lycopersicum esculentum is an herbaceous annual in the family Solanaceae grown for its edible fruit. The plant can be erect with short stems or vine-like with long, spreading stems. The stems are covered in coarse hairs and the leaves are arranged spirally. The tomato plant produces yellow flowers, which can develop into a cyme of $3-12$, and usually a round fruit (berry) which is fleshy, smoothed skinned and can be red, pink, purple, brown, orange or yellow in color. The tomato plant can grow 0.7-2 $\mathrm{m}(2.3-6.6 \mathrm{ft})$ in height and as an annual, is harvested after only one growing season. Tomato may also be referred to as love apple and originates from South America. [https://plantvillage.org/topics/tomato/infos.] It is one of the most profitable crops in the country and it is the second most important fruit vegetable in terms of area and volume of production. In 2001, a total of 17700 hectares were planted to the crop, producing 173700 metric tons valued at Php1, 808.7 million, which was equivalent to \$36.17 million US dollars [Altoveros, C.N and Borromeo, H.T., 2007].

Tomato is a day neutral plant; hence, it needs different temperatures at different growth stages as follows: seed germination requires $26^{\circ} \mathrm{C}$ to $32^{\circ} \mathrm{C}$, seedling growth $25^{\circ} \mathrm{C}$ to $26^{\circ} \mathrm{C}$, pollen tube germination and pollen tube growth requires $22^{\circ} \mathrm{C}$ to $27^{\circ} \mathrm{C}$, fruit setting $18^{\circ} \mathrm{C}$ to $20^{\circ} \mathrm{C}$ and fruit ripening requires $24^{\circ} \mathrm{C}$ to $28^{\circ} \mathrm{C}$. High day temperatures of more than $40^{\circ} \mathrm{C}$ can abort the flowers due to physical destruction of the pollen grains. It thrives in many soil types and it grows best in fairly fertile, well-drained sandy loam or heavier soils and soil free from root knot nematodes and bacterial wilt organism. Soil organic matter content at least $1.5 \%$ and $\mathrm{pH}$ at 4.3 to 8.7 , although growth is optimum at pH 5.5 to 6.5. It is tolerant to moderate acidic soil. Requires $460 \mathrm{~mm}$ of rainfall per cropping season, sensitive to water logging; and tolerate water logging for less than 7-8 hours [Phil Rice. 2007].

Tomato during rainy season could not produce fruits in an open area due to heavy rain that cause abortion of developed fruit. Pest and diseases which are also threat of tomato during this season that causes losses to most growers. Prices found to be very attractive due to lack of supply, if only famers could learn to manage the cover in order to protect the crops from heavy rain and pest and diseases that possibly attack the plants during rainy season. It could probably be a good source of income on the part of the farmers.

Previous trials have demonstrated the benefit of using row covers to enhance early growth of warm season crops like melons and peppers. There are many types of covers available and it is important to select the type of covering materials that best suit the 
needs of the crop; hence, this study examined the best row covers on the performance of tomato under off -season planting.

Eco-friendly net covers modified the microclimate resulting in significantly higher day temperatures and relative humidity, compared with the open treatment. Nets increased temperature and relative humidity by $14.8 \%$ and $10.4 \%$, respectively. Starting seeds under a net advanced seedling emergence by 2 days resulted in higher emergence percentage, thicker stem diameter, more leaves, and faster growth leading to early maturity of seedlings and readiness for transplanting. Netting improved root development by increasing root quantity and length and the use of eco-friendly nets (EFNs) and floating row covers (FRCS) in protected cultivation was tested in Africa and Europe, respectively and proved to be effective in microclimate modification. EFNs were also used in Kenya to improve tomato and cabbage transplant production. As a result of microclimate improvement, EFNs and FRCs have been reported to significantly alter air temperature and soil moisture which influence plant growth through changes in leaf characteristics, biomass accumulation and relative growth rate leading to a better yield and crop quality [Gogu, Saidi, Itulya,Martin,Ngouajio 2012].

An application of indigenous mulching materials such as dried papaya leaves could also make the plants grow past and retard the growth of weeds around the plants. These materials which are added to the soil are collectively termed as indigenous mulch. Other indigenous mulches as include grass clippings, bark, sawdust, and manure, hay straw, shells, woodchips, shredded newspaper, cardboard, and wool. [Acayen, Mandaraog, Mariano and Rivero, 2005],

Mulching is the process of practice of covering the soil/ground to make more favorable for plant growth. It prevents the direct evaporations of moisture from the soil thus limits the water losses and conserves moisture. Mulch can facilitate fertilizer placement and reduce the loss of plant nutrient through hatching [Dalorima L.T.Bunu A.,KyariZ.,Mohammed T.2014]. In the process also, the roots of plants can be protected from extreme temperature and moisture changes. It minimizes soil erosion and compaction from heavy rains, limits growth of weeds near plants, and indigenous mulch that is derived from plant material will decompose [Nisnisan, 2014].

According to Acayen, Mandaraog, Mariano and Rivero, [2005], indigenous mulches also help enriched the soil with nutrients as they breakdown. The added bonus is that cost is minimal. It can also suppress annual weeds and offer other important benefits, such as organic matter, nutrients, moisture conservation, soil protection and moderation of soil temperature. Rice hull is becoming a problem in rural areas, especially the operator of rice mill machine. Most farmers are not aware of the use of carbonized 
rice hull (CRH) as mulching materials for vegetables. Sawdust are just burned and turned into ash without any beneficial impact on the soil and that can contribute to high carbon dioxide emission that can be obtained from burning. Using sawdust as mulching materials can enrich the soil when these materials decomposed and incorporated to the soil during land preparation for the next cropping.

\section{Objectives of the Study}

The study generally aimed at evaluating the effects of shading and mulching materials in terms of growth and yield of tomato under off season production. Specifically, to determine the Best Eco-friendly net cover that promote the growth and increase yield of tomato plants; Best mulching materials that favor best growth and yield of tomatoes; Suitable variety that give promising yield with eco-friendly net cover, and mulching as management interventions; Interaction effect between and among eco-friendly covers and mulching materials; Correlation on temperature and relative humidity; andincome derived by using EFNC, mulching materials, tomato varieties and their combinations.

\section{Materials and Methods}

\subsection{Site description,construction of the cover and mulching}

The study was conducted over a span of 4 months from July to October in the field of the Ilocos Sur Polytechnic State College from June 2016 to October 2016. The area was thoroughly prepared using a tractor rotovator. It was plowed and horrowed twice to attain the best soil silt tilt before planting. Before covering the plots with EFN or FRC, all plots recieved a blanket spray of insecticide to prevent pest attack during the planting stage. Wood Post with around 2-3 in. in diameter and $2 \mathrm{~m}$ long was errected ino.5 mdeep hole. Sliced bamboo with around 2 in. wide and $4 \mathrm{~m}$ long was attached to the wood post using carpentry nail to fasten it firmly. Six wood post in every plot were established. Using a string, the Eco- Friendly Net, and UV Film were attached to the wood post to serve as a cover of the plants. Rope made of yarns, plies or strands that were twisted or braided together into a larger and stronger form were used to fix and put the cover in place. Plastic Mulches were laid on a prepared soil surface, which was free from trash and anchored using the weight of the soil on the edges. Carbonized Rice Hull was ordered from the farmers, then placed in 1-in. thick before transplanting. One-inch thick sawdust was distributed over the bed before transplanting. 


\subsection{Experimental design and treatments}

The study was laid on Split -Split Plot Design in Factorial Randomized Complete Block Design with three factors and three treatments replicated three times Each plot has a dimension of $2 \mathrm{~m} \times 5.5 \mathrm{~m}$ with an alley way of $1 \mathrm{~m}$ between plots and $1.5 \mathrm{~m}$ between replications having 10 experimental plants for each replication with a total area of 594 sq.m. The different treatments were as follows: Factor A- Eco-Friendly Net Covers (EFNCS) UV Film (Polyethylene) Control, EFNC blue, EFNC green. Factor B- Varieties of Tomatoes; Diamante Max F1, Marimar F1. Factor C Mulching Materials; Plastic Mulch Control, Sawdust, Carbonized Rice Hull.

\subsection{Planting materials}

Seeds of the two tomato varieties Diamante Max F1 and Marimar F1, which were used in the study were purchased from Abra Vegetable Seed growers Cooperative. Seeds were sown singly in a seedling tray to produce healthy and uniform seedlings and also to prevent transplanting shock due to healthier and stronger roots. The tray has 101 cells, each of which was filled with one part compost, one part processed animal waste and 1 part carbonized rice hull.

\subsection{Data gathered}

Height was taken 2 weeks after transplanting. Ten sample plants were measured for every treatment per replication using a meter stick and height at maturity was measured a week before the final harvesting. Number of branches per plant lateral branches arising from the nodes of the sample plant were counted and recorded after harvesting the third fruit. Number of flowers Per Plant determined by counting all the flowers per plant and marking them by tying a string on the base of the counted flowers to avoid confusion or possible repetition of counting. Fruit setting percentage was computed by counting all the number of flowers per plant and divided by the number of developed fruits per plant times 100. Number of harvested fruits per plant determined by counting all the harvested fruits per plant in all fruit priming's. Weight of harvested fruits per plot was weighed using a weighing scale to determine the weight of harvested fruits per tunnel. The total weight of harvested fruits in all fruit priming's was used in determining the fruit yield of tomato per hectare. An anemometer was 
used for monitoring the moisture and temperature for 10:00 AM and 3:00 PM inside the tunnel. Price of harvested tomato fruits that was based on current market price.

\subsection{Analysis of data}

All data gathered were arranged, tabulated, presented and analyzed based on the Split-Split Plot in Factorial Randomized Complete Block Design. A post hoc test was done using Tukey's Honest Significant Difference to determine which among the treatment means were significantly different from the other treatment means, and the Statistical Analysis for Agricultural Research (STAR).

\section{Results and Discussions}

\subsection{Height of the plants}

\subsubsection{EFNCS}

Height of tomato plants at 2 WAT and at maturity are presented in Table 1 that tomato plants in the (EFNC3) Green and (EFNC2) blue have comparable effects on the height of tomatoes during off-season planting as shown in the ANOVA (Appendix Table 1). The result implies that the different eco-friendly floating covers have similar effects on the growth of tomato plants both at early growth and at maturity.

TABLE 1: Net Cover x Variety Interaction table.

\begin{tabular}{|l|c|c|c|c|c|}
\hline Variety & \multicolumn{5}{|c|}{ Net Cover } \\
\hline & EFNC1 & EFNC2 & EFNC3 & Total & \\
\hline V1 & 185.80 & 196.83 & 198.80 & 581.43 & 21.53 \\
\hline V2 & 110.88 & 108.50 & 113.43 & 332.81 & 12.33 \\
\hline Total & 296.68 & 305.33 & 312.23 & 914.24 & \\
\hline Mean & 16.48 & 16.96 & 17.35 & & 16.93 \\
\hline
\end{tabular}

\subsubsection{Effects of variety}

Two varieties of tomato showed significant differences in growth at 2 weeks after planting and at maturity. "Diamante F1" was taller than "Marimar F1" with $21.53 \mathrm{~cm}$ at 2 weeks after planting and $52.48 \mathrm{~cm}$ at maturity, respectively. This difference is due to the genetic and agronomic characteristics of the varieties. This difference in height 
is attributed to the description of the East-West Seed Company that 'Diamante Max F1to be more robust and indeterminate compared to 'Marimar F1, which is physically smaller (Farm On.ph, 2017).

\subsubsection{Effect of mulch}

A significant difference on the effect of mulching materials on the growth of tomatoes both, at 2 weeks after planting and at maturity (Table 1). Plants with plastic mulch and with CRH comparably promoted plant growth at 2 weeks after planting. However, plants under $\mathrm{CRH}$ mulch were tallest at maturity. This is due to the characteristic effects of CRH on plant growth that contains K, P, Ca, Mg and microelements. (Phil Rice, 2015).

\subsubsection{Interaction effects of EFNCs and variety}

- ANOVA (Appendix Table 1c) showed no significant differences among treatment means this implies that height of tomato plants regardless of varieties was not affected by the EFNC.

\subsubsection{Interaction effects of EFNCs and mulching}

Comparable results with EFNC covers and mulching materials were obtained (Appendix Table 1). This shows that EFNC, and different mulching materials used exhibited no significant effects on the height of tomato plants 2 weeks after planting and at maturity.

\subsubsection{Interaction effects of net covers, variety and mulching materials}

Appendix Table 2 shows the mean height of tomatoes at maturity as affected by net covers, variety and mulching materials. Interaction effects of EFNC1 (UVFilm), Variety 1 ('Diamante $\mathrm{F}^{\prime}$ ') and $\mathrm{CRH}$ mulch have shown highest growth. However, ANOVA (Appendix Table 2d) shows no significant differences. In Table 2, significant differences among treatment means were not detected in EFNCs x variety, eco-friendly cover mulch and eco-friendly covers variety $x$ mulch. This indicates that any of the two variety used responded similarly, regardless of net covers even when combined with mulch and multiple combination of net covers, which were efficient in conserving soil moisture favorable to plant growth and beneficial effects in suppressing pest [ Gogo, O.E, Saidi, M. Itulya M. F, Martin,T.,Ngouajio, M. 2012] and their effectiveness in 
reducing soil temperature even in hot sunny days [Streck, N.A. et al.,1995]. Henceforth, the choice of net covers to use should be based on their economic advantage and availability in the locality.

TABLE 2: Net cover $x$ mulch interaction table.

\begin{tabular}{|c|c|c|c|c|c|}
\hline \multirow[t]{2}{*}{ Net cover } & \multicolumn{4}{|c|}{ Mulch } & \multirow[t]{2}{*}{ Mean } \\
\hline & $M_{1}$ & $M_{2}$ & $M_{3}$ & Total & \\
\hline $\mathrm{EFNC}_{1}$ & 99.80 & 96.23 & 100.65 & 296.68 & 16.48 \\
\hline EFNC2 & 109.04 & 90.95 & $105 \cdot 34$ & 305.33 & 16.96 \\
\hline $\mathrm{EFNC}_{3}$ & 101.58 & 101.75 & 108.90 & 312.23 & 17.35 \\
\hline Total & 310.42 & 288.93 & 314.89 & 914.24 & \\
\hline Mean & 17.25 & 16.05 & 17.49 & & 16.93 \\
\hline
\end{tabular}

TABLE 3: Variety $x$ mulch interaction table.

\begin{tabular}{|c|c|c|c|c|c|}
\hline \multirow[t]{2}{*}{ Variety } & \multicolumn{4}{|c|}{ Mulch } & \multirow[t]{2}{*}{ Mean } \\
\hline & $M_{1}$ & $M_{2}$ & $M_{3}$ & Total & \\
\hline$V_{1}$ & 198.80 & 184.73 & 197.90 & 581.43 & \\
\hline$V_{2}$ & 111.62 & 104.20 & 116.99 & 332.81 & \\
\hline Total & 310.42 & 288.93 & 314.89 & 914.24 & \\
\hline Mean & 17.25 & 16.05 & 17.49 & & 16.93 \\
\hline
\end{tabular}

TABLE 4: Summary table for the analysis of variance (ANOVA).

\begin{tabular}{|c|c|c|c|c|c|c|}
\hline $\begin{array}{l}\text { Source of } \\
\text { Variation }\end{array}$ & df & SS & MS & $\begin{array}{c}\text { Tab. F.Value } \\
\text { TFV }\end{array}$ & 0.05 & 0.01 \\
\hline Replication & 2 & 3.3768 & 1.6884 & 1.3846 & & \\
\hline Net cover & 2 & 6.7453 & 3.3727 & $2.7657^{n s}$ & 6.94 & 18.00. \\
\hline Error(a) & 4 & 4.8778 & 1.2195 & & & \\
\hline Variety & 1 & 1144.6656 & 1144.6656 & $332.9398 * *$ & 5.99 & 13.74 \\
\hline EFNCXV & 2 & 5.5150 & 2.7575 & $0.8021^{n s}$ & 5.14 & 10.92 \\
\hline Error (b) & 6 & 20.6283 & 3.4381 & & & \\
\hline Mulch & 2 & 21.4038 & 10.7019 & $4.0788^{*}$ & 3.40 & 5.61 \\
\hline EFNCXM & 4 & 16.69 .43 & 4.1736 & $1.5907^{n s}$ & 2.78 & 4.22 \\
\hline$V \times M$ & 2 & 1.5479 & 0.7740 & $0.2950^{n s}$ & 3.40 & 5.61 \\
\hline $\begin{array}{l}\text { EFNC } \\
x V x M\end{array}$ & 4 & 3.6086 & 0.9021 & & & \\
\hline Error (c) & 24 & 62.9705 & 2.6238 & $0.3438^{n s}$ & 2.78 & 4.22 \\
\hline Total & 53 & 1292.0341 & & & & \\
\hline \multicolumn{7}{|c|}{$\star *$ - Highly significant cv(a) $=6.52 \%$} \\
\hline \multicolumn{7}{|c|}{ * - Significant $c v(b)=10.95 \%$} \\
\hline Ns-Not sign & ifica & $\operatorname{tav}(c)=9.5$ & & & & \\
\hline
\end{tabular}


TABLE 5: Summary table for the analysis of variance (ANOVA).

\begin{tabular}{l|c|c|c|c|c|c|}
\hline $\begin{array}{l}\text { Source of } \\
\text { Variation }\end{array}$ & $\mathrm{df}$ & $\mathrm{SS}$ & $\mathrm{MS}$ & $\begin{array}{c}\text { Tab. F.Value } \\
\text { TFV }\end{array}$ & 0.05 & 0.01 \\
\hline Replication & 2 & 1064.2717 & 532.1359 & 6.6429 & & \\
\hline Net cover & 2 & 38.8203 & 19.4102 & $0.2423^{n s}$ & 6.94 & 18.00 \\
\hline Error(a) & 4 & 320.4236 & 80.1059 & & & \\
\hline Variety & 1 & 735.4187 & 735.4187 & $12.6425^{*}$ & 5.99 & 13.74 \\
\hline EFNCxV & 2 & 56.8139 & 28.4070 & $0.4883^{n s}$ & 5.14 & 10.92 \\
\hline Error (b) & 6 & 349.0209 & 58.1702 & & & \\
\hline Mulch & 2 & 5334.0807 & 2667.0404 & $27.2971^{\star *}$ & 3.40 & 5.61 \\
\hline EFNCxM & 4 & 340.7012 & 85.1753 & $0.8718^{n s}$ & 2.78 & 4.22 \\
\hline V x M & 2 & 164.4754 & 82.2377 & $0.8417^{n s}$ & 3.40 & 5.61 \\
\hline EFNC xVxM & 4 & 330.1940 & 82.5485 & $0.8449^{n s}$ & 2.78 & 4.22 \\
\hline Error (c) & 24 & 2344.9009 & 97.7042 & & & \\
\hline Total & 53 & 11079.1214 & & & &
\end{tabular}

While plastic mulches retain soil moisture but raise soil temperature that maybe detrimental to plant growth. Organic mulches offer the same moisture retaining capacity, suppress weeds and fruiting advantages, Moreover, decomposing materials may add soil organic matter beneficial to plants [Sideman,2017]. Further, he found that tomatoes can be mulched with straw, pine needles or leaves, spread 2-4 inches deep around the base of the plants. Nevertheless, black plastic mulch suppresses weeds and protects fruits of unstaked plants from covering in contact with the soil. Regardless of variety and net cover, $\mathrm{CRH}$ and other organic mulches are more advantageous than plastic or synthetic mulch.

\subsection{Number of branches per plant as affected by individual treatment}

\subsubsection{EFNCS}

Table 2 presents the effects of eco-friendly net covers on the number of branches per tomato plant. ANOVA showed no significant differences among treatment means. This implies that EFNCs do not have any significant impact on the number of branches produced per plant. 


\subsubsection{Effects of variety}

The numbers of branches produced per plant are likewise presented in Table 2. The ANOVA(Appendix Table 3a) shows no significant differences among means, which implies that the number of branches produced was a varietal characteristic. Both varieties are good at producing branches throughout their growing season.

\subsubsection{Effects of mulching materials}

The number of branches produced per plant showed that $\mathrm{CRH}\left(\mathrm{M}_{3}\right)$ produced the most number of branches with a mean of 3.61 branches per plant (Table 2); followed by Plastic Mulch $\left(M_{1}\right)$ with a mean of 3.35 branches per plant and Sawdust had the lowest number of branches per plant with a mean of 3.18. The ANOVA in Appendix Table 3b revealed highly significant result, which implies that various mulching materials applied on tomato plants have different effects on the number of branches per plant. On the comparison among means, tomato plants mulched with $\mathrm{CRH}\left(\mathrm{M}_{3}\right)$ produced significantly higher number of branches per plant as against Plastic Mulch $\left(M_{1}\right)$ and Sawdust $\left(M_{2}\right)$. Likewise, Plastic Mulch $\left(M_{1}\right)$ produced significantly higher branches per plant when compared to Sawdust $\left(M_{2}\right)$. This corroborates what Sideman (2017) stressed; that while black plastic mulch suppresses weeds, and also protects the fruit of a staked plant from coming into contact with soil, organic mulches like carbonized rice hull offers more benefits. Moreover, organic mulch offers the same moisture retaining capacity, weed suppressing and fruit protecting advantages as plastic, but the latter offers more benefits as it eventually decompose, adding to the soil's supply of organic matter, and thus producing more branches per plant.

\subsubsection{Interaction effects of EFNCs and variety}

The combined effects of EFNCS and variety (V) showed no significant interaction effects (Appendix Table 3a). The results imply that any of the varieties and any of the floating covers could be used during off- season production. 
TABLE 6: Summary table for the analysis of variance (ANOVA).

\begin{tabular}{l|c|c|c|c|c|c|}
\hline $\begin{array}{l}\text { Source of } \\
\text { variation }\end{array}$ & $\mathrm{df}$ & $\mathrm{SS}$ & $\mathrm{MS}$ & $\begin{array}{c}\text { Tab.F.Value } \\
\text { TFV }\end{array}$ & 0.05 & 0.01 \\
\hline Replication & 2 & 0.0370 & 0.0185 & 0.6968 & & \\
\hline EFNC & 2 & 0.0826 & 0.0413 & $1.5541^{n s}$ & 6.94 & 18.00 \\
\hline Error (a) & 4 & 0.1063 & 0.0266 & & \\
\hline Variety & 1 & 0.0224 & 0.0224 & $1.5699^{n s}$ & 5.99 & 13.74 \\
\hline NC x V & 2 & 0.0804 & 0.0402 & $2.8187^{n s}$ & 5.14 & 10.92 \\
\hline Error (b) & 6 & 0.0856 & 0.0143 & & & \\
\hline Mulch & 2 & 1.6281 & 0.8141 & $31.9712^{* *}$ & 3.40 & 5.61 \\
\hline NC x M & 4 & 0.0785 & 0.0196 & $0.7709^{n s}$ & 2.78 & 4.22 \\
\hline V x M & 2 & 0.0193 & 0.0096 & $0.3785^{n s}$ & 3.40 & 5.61 \\
\hline NC x V x M & 4 & 0.0163 & 0.0041 & $0.1600^{n s}$ & 2.78 & 4.22 \\
\hline Error (c) & 24 & 0.6111 & 0.0255 & & & \\
\hline Total & 53 & 2.7676 & & & &
\end{tabular}

\subsubsection{Interaction effects of EFNCs and mulching materials}

Result showed that the nine treatment combinations have comparable effects. However, EFNC Green covered tomato mulched with CRH (EFNC3 $\times M_{3}$ ) increased the number of branches per plant with a mean of 3.69 (Appendix Table 1a).

\subsubsection{Interaction effects of variety and mulching materials}

The combined effects of variety and mulching materials on the number of branches produced by an individual tomato plant are presented in Appendix Table 3c. Result reveals that EFNC1 (UV Film) and Marimar mulched with $\mathrm{CRH}_{2}\left(\mathrm{~V}_{2} \times \mathrm{M}_{3}\right)$ showed the most number of branches produced per plant with a mean of 3.65 branches, but the differences were not significantly different with other combinations/interactions. ANOVA reveals not significant result, regardless of variety to plant and mulching material to use, the same number of branches is produced by the tomato plant. 


\subsubsection{Interaction effects of EFNCs, variety and mulching materials}

Although the combined effects of UV Film tunnel, Marimar variety and CRH mulch (EFNC1 $\times V_{2} \times M_{3}$ ) showed the most number of branches among all other treatment combinations but no significant differences were observed in ANOVA shown in Appendix Table $3 \mathrm{~d}$ which implies that the three treatment combinations did not have any significant impact on the growth of tomato plants, particularly on the number of branches produced per plant. All the variables whether individual or in combination, except mulching treatments did not influence the branching ability of tomato as shown in (Table 3). The two varieties of tomato responded similarly, regardless of net cover even in combination with mulch. Moreover, mulching tomatoes with $\mathrm{CRH}$ produced more number of branches with a mean of 3.61 branches/plant; followed by plastic mulch 3.25 branches /plant and the least from Sawdust with a mean of 3.18 branches/plant. This could be due to the nutrients present in the organic mulch that favors branching. This corroborates the study of Sideman (2017); that black plastic mulch suppresses weeds, and also protects the fruit of unstaked plants from coming into contact with soil, organic mulches like CRH offers more benefits. Moreover, organic mulch offers the same moisture retaining, weed suppressing and fruit protecting advantages as plastic, but the latter offers more benefits as it eventually decompose, adding to the soil's supply of organic matter, and thus, more branches per plant are produced.

\subsection{Number of flowers, fruiting percentage and number of fruits developed per plant}

The effects of the three treatments are presented in Table 3.

\subsubsection{EFNCs}

Isolated as an individual treatment, regardless of the variety and mulching materials used, EFNCs did not have significant effects on the number of flowers, number of fruits developed and percentage of fruits produced per plant as shown in Table 3 and Appendix Table $4 a$. 
TABLE 7: Summary table for the analysis of variance (ANOVA).

\begin{tabular}{|c|c|c|c|c|c|c|}
\hline $\begin{array}{l}\text { Source of } \\
\text { variation }\end{array}$ & $d f$ & SS & MS & $\begin{array}{c}\text { Tab.F.Value } \\
\text { TFV }\end{array}$ & 0.05 & 0.01 \\
\hline Replication & 2 & 14.8724 & 7.4362 & 0.4213 & & \\
\hline EFNC & 2 & 39.4766 & 19.7383 & $1.1184^{n s}$ & 6.94 & 18.00 \\
\hline Error (a) & 4 & 70.5977 & 17.6494 & & & \\
\hline Variety & 1 & 2.1629 & 2.1629 & $0.1726^{n s}$ & 5.99 & 13.74 \\
\hline$N C \times V$ & 2 & 10.0611 & 5.0305 & $0.4014^{n s}$ & 5.14 & 10.92 \\
\hline Error (b) & 6 & 75.1901 & 12.5317 & & & \\
\hline Mulch & 2 & 1475.2526 & 737.6263 & $31.6664^{* *}$ & 3.40 & 5.61 \\
\hline$N C \times M$ & 4 & 18.0729 & 4.5182 & $0.1940^{n s}$ & 2.78 & 4.22 \\
\hline$V \times M$ & 2 & 9.5671 & 4.7836 & $0.2054^{n s}$ & 3.40 & 5.61 \\
\hline$N C \times \vee \times M$ & 4 & 69.8339 & 17.4585 & $0.7495^{n s}$ & 2.78 & 4.22 \\
\hline Error (c) & 24 & 559.0473 & 23.2936 & & & \\
\hline Total & 53 & 2344.1345 & & & & \\
\hline \multicolumn{7}{|c|}{ ** - Highly significant cv (a) $=8.94 \%$} \\
\hline \multicolumn{7}{|c|}{ * - Significant cv (b) = 7.53\% } \\
\hline \multicolumn{7}{|c|}{ Ns - Not significant cv $(c)=10.27 \%$} \\
\hline
\end{tabular}

\subsubsection{Effects of variety}

ANOVA reveals no significant differences, which implies that the two varieties used produced the same number of flowers per plant, number of developed fruits and fruiting percentage regardless of EFNCs.

\subsubsection{Effects of mulching materials}

Plastic mulch, sawdust and CRH had very high significant effects on the number of flowers produced per plant, number of developed fruits and fruiting percentage as shown in Table 3. Shows that mulching can facilitate fertilizer placement and reduce the loss of plant nutrients [Dalorima L.T.Bunu A.,Kyari Z.,Mohammed T.2014]. In the process, the roots of plants can be protected from extreme temperature and moisture changes. In addition, it minimizes soil erosion and compaction from heavy rains, limits growth of weeds near plants, and indigenous mulch that is derived from plant material will decompose [Nisnisan, 2014]. Highest flower, fruit set was obtained from plants mulched with $\mathrm{CRH}$ with a mean 56.73, 23.30, and 42.80 respectively. This is due to the characteristics of $\mathrm{CRH}$ that has the ability to absorb and retain moisture and nutrients [Sideman, 2017]. Indigenous mulches also help enriched the soil with nutrients as they 
breakdown, while minimal cost is an added bonus. [Acayen, M.T., L.G. Magdaraog,L.G, Matriano, and L. M. Rivero 2005].

\subsubsection{Interaction effects EFNCs and variety}

Appendix Table 4, 5 and 6 showed treatment means of the interaction effects of EFNC $x$ variety. The ANOVA shows no significant differences among treatment mean combinations. This goes to show that any of the variety and net covers can be used as a cultural practice for tomato production when number of flowers per plant, fruit setting percentage will be the parameter to be considered.

TABLE 8: Summary table for the analysis of variance (ANOVA).

\begin{tabular}{l|c|c|c|c|c|c|}
\hline $\begin{array}{l}\text { Source of } \\
\text { variation }\end{array}$ & Df & SS & MS & $\begin{array}{c}\text { Tab.F.Value } \\
\text { TFV }\end{array}$ & 0.05 & 0.01 \\
\hline Replication & 2 & 19.4957 & 9.7478 & 2.0208 & & \\
\hline EFNC & 2 & 1.2582 & 0.6291 & $0.1304^{n s}$ & 6.94 & 18.00 \\
\hline Error (a) & 4 & 19.2954 & 4.8239 & & & \\
\hline Variety & 1 & 0.0687 & 0.0687 & $0.0133^{n s}$ & 5.99 & 13.74 \\
\hline NC x V & 2 & 13.7703 & 6.8851 & $1.3325^{n s}$ & 5.14 & 10.92 \\
\hline Error (b) & 6 & 31.0028 & 5.1671 & & & \\
\hline Mulch & 2 & 451.2036 & 225.6018 & $38.8747^{* *}$ & 3.40 & 5.61 \\
\hline NC x M & 4 & 2.8640 & 0.7160 & $0.1234^{n s}$ & 2.78 & 4.22 \\
\hline V x M & 2 & 3.3213 & 1.6606 & $0.2862^{n s}$ & 3.40 & 5.61 \\
\hline NC x V x M & 4 & 16.2380 & 4.0595 & $0.6995^{n s}$ & 2.78 & 4.22 \\
\hline Error (c) & 24 & 139.2795 & 5.8033 & & & \\
\hline Total & 53 & 697.7975 & & & & \\
\hline ** - Highly significant cv (a) $=11.89 \%$ & & &
\end{tabular}

\subsubsection{Interaction effects of EFNCs and mulching material}

Tomatoes, regardless of floating covers, varieties or mulching materials used have the same flower production, fruiting percentage, number of fruits developed during the off-season planting as shown in the ANOVA, which did not show significant differences. Results imply that during off-season tomato production, any of the treatments could be used. Other factors were involved in flower formation such as the microclimatetemperature [Hatfield, J. L and J.H. Prueger, 2015]. 
TABLE 9: Summary table for the analysis of variance (ANOVA).

\begin{tabular}{l|c|c|c|c|c|c|}
\hline $\begin{array}{l}\text { Source of } \\
\text { variation }\end{array}$ & Df & SS & MS & $\begin{array}{c}\text { Tab.F.Value } \\
\text { TFV }\end{array}$ & 0.05 & 0.01 \\
\hline Replication & 2 & 73.3750 & 36.6875 & 4.1681 & & \\
\hline EFNC & 2 & 9.0851 & 4.5425 & $0.5161^{n s}$ & 6.94 & 18.0 \\
\hline Error (a) & 4 & 35.2079 & 8.8020 & & & \\
\hline Variety & 1 & 2.5295 & 2.5295 & $0.2337^{n s}$ & 5.99 & 13.74 \\
\hline NC x V & 2 & 26.4983 & 13.2491 & $1.2241^{n s}$ & 5.14 & 10.92 \\
\hline Error (b) & 6 & 64.9416 & 10.8236 & & & \\
\hline Mulch & 2 & 207.4097 & 103.7049 & $13.5550^{* *}$ & 3.40 & 5.61 \\
\hline NC x M & 4 & 14.2116 & 3.5529 & $0.4644^{n s}$ & 2.78 & 4.22 \\
\hline V x M & 2 & 3.1727 & 1.5864 & $0.2074^{n s}$ & 3.40 & 5.61 \\
\hline NC x V x M & 4 & 3.1979 & 0.7995 & $0.1045^{n s}$ & 2.78 & 4.22 \\
\hline Error (c) & 24 & 183.6160 & 7.6507 & & & \\
\hline Total & 53 & 623.2454 & & & &
\end{tabular}

\subsubsection{Interaction effects of variety and mulching materials}

Marimar $F_{1}$ when mulched with $\mathrm{CRH}\left(\mathrm{V}_{2} \times \mathrm{M}_{3}\right)$ had produce the most number of flowers per plant, number of fruits developed and highest fruiting percentage with a mean of 53.04, 21.90 and 41.78 respectively as shown in Appendix Table 4,5 and 6. However no significant differences were observed, while both are organic in nature, the difference is due to the ability of $\mathrm{CRH}$ to absorb and retain moisture and nutrients for the benefits of the tomato plant [Sideman, 2017].

\subsubsection{Interaction effects of EFNCs, variety and mulching materials}

Any treatment combinations of EFNC $x$ Variety $x$ mulch did not have any significance differences in terms of the number of flowers, fruit setting percentage and number of fruits developed [Appendix Tables 4,5 and 6].

\subsection{Number and weight of marketable fruits/plant}

The data on the number and weight of marketable fruits per plant as affected by EFNCs, variety and mulching materials are presented in Table 4. 


\subsubsection{Effects of EFNCs}

EFNCs have comparable effects on the number and weight of marketable fruits. The analysis of variance in Appendix Table $7 \mathrm{~d}$ shows no significant differences among the means of EFNCs, which goes to show that any of them can be used as net cover on tomato plants.

\subsubsection{Effects of variety}

ANOVA showed no significant difference among treatment means. The result implies that both varieties performed similarly under any of the EFNCs.

\subsubsection{Effects of mulching materials}

Shown in Table 4, the number and weight of marketable fruits CRH with a mean of 18.25 fruits per plant obtained the highest marketable fruits, while Plastic Mulch (M1) had the highest weight of marketable fruits per plant with a mean of $9.02 \mathrm{~kg} / \mathrm{plot}$. ANOVA shown in the Appendix Table reveals highly significant result in both number and weight of marketable fruits per plant. The significantly high production of marketable fruits per plant in CRH mulched tomato plants was attributed to the efficiency of mulch, particularly $\mathrm{CRH}$, in minimizing evaporation of soil water, suppressing weeds and maintaining soil temperature beneficial to its growth of tomato plants. In addition, it has the ability to prevent diseases of tomato due to its growth retardant effects, just like charcoal, on disease-causing microorganisms; thus, increased number of marketable fruits per plant [Acayen, et al, 2004; Nisnisan, 2014]. On the other hand, during rainy seasons, Plastic Mulch prevents the soil from soaking water and thus maintains soil aeration. In addition, it minimizes the occurrence of diseases as a result of too much water. Moreover, it minimizes soil erosion and compaction from heavy rains, limits growth of weeds near plants. Indigenous mulch that is derived from plant material will decompose, and thus their mulching function may decrease as the plant matures [Nisnisan, 2014]. 


\subsubsection{Interaction effects of EFNCs and variety}

ANOVA reveals no significant differences among treatment means. This implies that any of the covers can be adopted by farmers depending upon its availability in the агеа.

\subsubsection{Interaction effects of EFNCs and mulching materials}

Effects of EFNCs with mulching materials did not differ significantly. The result of the ANOVA shown in (Appendix Table 7d) reveals, that all net covers and mulching material combined, produced comparable number and weight of marketable fruits per plant, which implies that any of the cultural practices of net covers and mulching materials be it organic or synthetic can be adopted for optimum production of tomato plants, in terms of number and weight of marketable fruits per plant.

TABLE 10: Summary table for the analysis of variance (ANOVA).

\begin{tabular}{l|c|c|c|c|c|c|}
\hline $\begin{array}{l}\text { Source of } \\
\text { variation }\end{array}$ & $\mathrm{df}$ & $\mathrm{SS}$ & $\mathrm{MS}$ & $\begin{array}{c}\text { Tab.F.Value } \\
\text { TFV }\end{array}$ & 0.05 & 0.01 \\
\hline Replication & 2 & 12.0396 & 6.0198 & 2.0038 & & \\
\hline EFNC & 2 & 9.4007 & 4.7004 & $1.5646^{n s}$ & 6.94 & 18.00 \\
\hline Error (a) & 4 & 12.0169 & 3.0042 & & & \\
\hline Variety & 1 & 0.8319 & 0.8319 & $0.1869^{n s}$ & 5.99 & 13.74 \\
\hline NC x V & 2 & 7.9027 & 3.9514 & $0.8878^{n s}$ & 5.14 & 10.92 \\
\hline Error (b) & 6 & 26.7040 & 4.4507 & & & \\
\hline Mulch & 2 & 401.0882 & 200.5441 & $41.5469^{* *}$ & 3.40 & 5.61 \\
\hline NC x M & 4 & 2.2708 & 0.5677 & $0.1176^{n s}$ & 2.78 & 4.22 \\
\hline V x M & 2 & 1.9772 & 0.9886 & $0.2048^{n s}$ & 3.40 & 5.61 \\
\hline NC x V x M & 4 & 11.0901 & 2.7725 & $0.5744^{n s}$ & 2.78 & 4.22 \\
\hline Error (c) & 24 & 115.8464 & 4.8269 & & & \\
\hline Total & 53 & 601.1685 & & & &
\end{tabular}

\subsubsection{Interaction effects of variety and mulching materials}

The combined effects of variety and mulching materials on the number and weight of marketable fruits per plant are presented in Appendix Table7. The ANOVA showed no significant result in both number and weight of marketable fruits. 


\subsubsection{Interaction effects of EFNCs, variety and mulch}

Appendix Table 5 and 7 showed the mean number and weight of marketable fruits. The ANOVA showed no significant result both on number and weight of marketable fruits.

\subsection{Yield}

\subsubsection{Effects of EFNCs}

Table 5 presents the mean yield per hectare $(\mathrm{kg} / \mathrm{ha}$ ) and income from harvested tomato fruits but no significant variations were found which suggest that net covers did not influence the yield.

\subsubsection{Effects of variety}

Appendix Table 9d and 10d yield and income per hectare were not significantly affected by the two varieties. However, numerical data show that Marimar F1 variety produced heavier marketable fruits and much more income than Diamante Max F1 by hundreds of kilograms and thousands of pesos (Table 5), respectively. However, the yield of the two varieties was a far cry from their potential yield of 9-10 t/ha [DA-BAS, 2016; Narciso and Balatero, 2008]. It was attributed to the fact that these varieties were grown off-season which produced a little lower yield than their usual potential.

\subsubsection{Effects of mulch}

Mulching materials significantly affected the yield of marketable fruits and income per hectare (Table 5). Data show that tomato mulched with plastic gave significantly higher mean yield and income per hectare of $3,682.14 \mathrm{~kg}$ and it can be attributed to the ability of plastic mulch to maintain microclimatic factors in the soil as a result of efficient covers [Nisnisan, 2014].

\subsubsection{Effects of EFNCs}

Cover materials did not significantly affect the yield of tomato plants as manifested in Table 5 . This implies that any Eco-Friendly cover can be adopted by farmers. 


\subsubsection{Interaction effects of EFNCs, variety and mulch}

Computed yield per hectare is derived from the weight of the harvested fruits per plot. Variety 2 (Marimar F1) obtained the highest yield of 3381.03 under EFNC 3 x Variety 2 $x$ Mulch 1, while the lightest was on the combination of EFNC 1 x Variety 1 x Mulch 2.

\subsection{Income}

\subsubsection{Effects of eco- friendly net covers}

The ANOVA on the income of tomato per hectare is presented in Table 5. Plastic Mulch (M1) generated the highest mean of Php 349,707.83 per hectare. Mean yield ranged from Php 297.010.76 to Php 313,224.14.

\subsubsection{Effects of variety}

As shown in Table 5 Variety 2 (Marimar F1) obtained the highest yield per hectare as shown by the results in ANOVA with an income of Php 311,553.49 as compared to Php 296,824.06 of Diamante Max F1.

\subsubsection{Effects of mulching materials}

Mulching materials results shows that Plastic Mulch obtained the highest yield per hectare as revealed in table 5 with an income of Php of 349,707.83 while other mulching materials ranged from Php 269,014.31 to Php 293,844.19.

\subsubsection{Interaction effects of EFNCs, variety and mulch}

Computed income as a result of the ROI, results shows that combination of EFNC3 $x$ Variety 2 x Mulch 1 generated the highest, least weight was on the combination of EFNC 1 x Variety 1 x Mulch 2 with a net income of Php 250,397.70.

\subsection{Correlation of temperature inside the tunnel on the plant height and yield of tomato}

The microclimatic conditions inside the EFNC include the temperature of different gathering period at 10:00 o'clock AM and 3:00 o'clock PM. The results of the mean internal 
temperature in the morning and in the afternoon were correlated to the different growth and yield parameters of tomato plants. These relationships are presented in scatter plots with regression equation $(y=b x+a)$, coefficient of determination $\left(R^{2}\right)$ and Pearson Product Moment correlations (r).as shown on Fig.2. 89x +665.54 , respectively).

\section{Conclusions}

Based from the results the following conclusions were derived: EFNCs did not significantly affect the growth and yield of tomato plants during off-season planting; Diamante Max F1 and Marimar F1 tomato varieties differed significantly in terms of height, but comparable with other growth and yield parameter; CRH significantly improved the growth of tomato, but plastic mulch was significantly better in producing higher yield and income per hectare; Higher temperatures inside the tunnel improved the growth of tomato plants in terms of height and number of branches per plant but lowered the weight of marketable fruits per plot and yield per hectare. Relative humidity (\%) had a downhill (negative) linear relationship with the growth of tomato plants; and high relative humidity $(\%)$ inside the tunnel increased the weight of marketable fruits per plot and yield per hectare.

\section{Recommendations}

For higher yield and income per hectare, use UV Films as eco-friendly net covers for tomato grown during off-season planting. Any of the two varieties (Diamante Max F1 or Marimar F1) can be used for off-season production. Use plastic mulch and Marimar F1 variety for higher yield, use UV films and plastic mulch to cover the plants. Temperature inside the tunnel should be higher during the early growth stages and slightly lower temperature inside the tunnel should be observed during the flowering and fruiting stages for better yield and for heavier fruits and more income relative humidity should be higher inside the tunnel. Further study should be conducted to compare plastic mulch and $\mathrm{CRH}$ in the production of off-season as well as other varieties for more conclusive result. 


\section{Author's Note}

MILAGROS OLIGO LIBERATO, Ilocos Sur Polytechnic State College Santa Maria Ilocos Sur. Graduate School Core Faculty

The study was a Dissertation Paper and it is made possible through the guidance and generous help of the Oral Examination Committee of the Don Mariano Marcos Memorial State University, Bacnotan,La Union. Her family and friends who extended moral and spiritual supports, the llocos Sur Polytechnic State College for their permission to conduct the research in the school farm.

\section{Conflicts of Interest}

The author declare no conflict of interest

Author Contact Number:09062963546

\section{References}

[1] ACAYEN, M.T.,L.G. MAGDARAOG,L.G, MATRIANO, and L. M. RIVERO. Dried papaya leaves as organic mulch for tomato plants. Abstract. Philippine Science High School Bicol Region Campus. Source Bato Balani for Science and Technology Vol.24 No. 1 SY 2004-2005. In Cooperation with DOST.

[2] ALTIVEROS, C.N. and BORROMEO,H.T.(2007). The state of the plant genetic resources for food and agriculture of the Philippines (1997-2004). A country report-DA-BPI

[3] DA,BAS 2016. Crop Production Statistics. Department of Agriculture. Bureau of Agricultural Statistics.

[4] DALURIMA L.T, BUNU A., MOHAMMED T. (2014). Effects of different mulcing materials on the growth performance of Okra in Maiguguri.http:/dx.doi.org/10.14303/irjas.2014.037.

[5] FARM ON,PH. (2017). Tomato production guide in the Philippines. Retrieved from http://community.farmon.ph/ printthread.php?tid = 784\&page $=1$.

[6] GOGO, O.E, SAIDI, M. ITULYA M. F, MARTIN,T.,NGOUAJIO, M. (2012). Microclimate modification using eco-friendly nets for high- quality tomato transplant production by small-scale farmers in East Africa.http://horttech.ashspublications.org/content/ 22/3/292.full.

[7] HATFIELD,J. L AND PRUEGER J.H(2015). Temperature extremes: Effect on plant growth and development.http://www.sciencedirect.com/science/article/pii/ 
S2212094715300116.

[8] https://plantvillage.org/topics/tomato/infos

[9] NARCISO, J.O. and C.H. BALATERO. 2008. 'Rica': A new off-season tomato variety. Philippine Journal of Crop Science. http://www.cabi.org/GARA/FullTextPDF/2009/ 20093005653.pdf.

[10] NISNISAN, B.M. (2014). Performance of tomato plant as affected by organic mulching Presented at DLSU research Congress 2014 De la Salle University, Manila, Philippines. www.dlsu.edu.ph/conferences/dlsu_research_congress/ ...SEE_1V_033_FT.pdf.

[11] PHILRICE, 2007. Training Guide for Palayamanan; Vegetable Production.

[12] Rudinas, J. S.(2009). Plant variety gazette. Volume V. Plant Variey Protection office. Bureau of Plant Industry, Department of Agriculture.

[13] http://www.pvpo.bpinsicpvpo.com.ph/downloads/gazette5.pdf.

[14] SIDEMAN, B. (2017). Growing Vegetables: Tomatoes. UNH Cooperative Extension. University of New Hampshire. https://extension.unh.edu/resources/files/ resourceoo0609_rep631.pdf.

[15] STRECK N.A. et.al. 1995. Effect of polyethylene mulches in soil temperature and tomato yield in plastic greenhouse. www.scielo.php?script+sci=arttex\&pid= s0103-9016199500300028. 